TAHKIII, Jurnal Peradaban dan Hukum Islam. Vol.3 No.2 (0ktober, 2020) | ISSN : 2597-7962

\title{
MENELISIK DINAMIKA DAN EKSISTENSI FATWA MUI SEBAGAI UPAYA MITIGASI PANDEMI COVID-19
}

\author{
Abdur Rahman Adi Saputera \\ Institut Agama Islam Negeri (IAIN) Sultan Amai Gorontalo \\ adisaputrabd@gmail.com
}

\begin{abstract}
ABSTRAK
Penelitian ini didesain dalam bentuk penelitian (Library Reserach) menggunakan berbagai sumber kepustakaan sebagai sumber data penelitian, dengan tujuan menelisik dan mengupas nilai-nilai eksistensi Fatwa MUI dalam upaya memitigasi Covid-19 yang jauh hari kian merajalela. Penelitian ini juga mengaplikasikan pendekatan deskriptif-normatif karena ditujukan untuk mendiskripsikan pandemi dan keberadaan Fatwa sebagai sebuah fenomena nyata, yang melahirkan beragam dinamika dan respon sosial masyarakat, serta berangkat dari bangunan sumber data primer dan sekunder sebagai pendukung, Dari data yang terkumpulkan melalui dokumen-dokumen yang interkorelatif dan tinjuan terhadap realita sosial di tengah masyarakat, penulis berusaha menganalisisnya melalui proses Descriptive Analytic Method Content sebagai pisau analisis. Hasil penelitian menunjukan bahwa, pada kenyataantanya peranan dan pengaruh fatwa MUI di masa pandemi sebagai wujud mitigasi covid-19 adalah langkah-langkah ideal dan strategis. Sekalipun di awal kehadirannya Fatwa Pandemi banyak mengalami berbagai macam dinamika, seperti pertentangan dan lain sebagainya. Namun pada akhirnya mendapatkan reaksi responsif dari semua kalangan, karena pada prinsipnya, eksistensi fatwa tersebut adalah wujud esensial dari alternatif dan solusi dalam menciptakan pola keberagamaan dan peribadatan yang lebih progresif, realistis, dinamis, dan kontekstualis, yang sekaligus menampilkan wajah Hukum Islam yang rahmatan lil alamin sholihul likulli zaman wal makan.
\end{abstract}

\section{Kata Kunci: Dinamika, Eksistensi, Fatwa MUI, Covid-19}

\begin{abstract}
This research is designed in the form of research (Library Research) using various sources of literature as a source of research data, with the aim of investigating and analyzing the values of the existence of the MUI Fatwa in an effort to mitigate Covid-19 which is becoming increasingly rampant. This study also applies a descriptive-normative approach because it is aimed at describing the pandemic and the existence of Fatwa as a real phenomenon, which gives birth to various dynamics and social responses in the community,
\end{abstract}


and departs from the building of primary and secondary data sources as support, from the data collected through documents. which is inter-correlative and a review of social realities in society, the author tries to analyze it through the Descriptive Analytic Method Content process as an analysis knife. The results show that, in fact, the role and influence of the MUI fatwa during the pandemic as a form of mitigating Covid-19 are ideal and strategic steps. Even though at the beginning of its existence, the Pandemic Fatwa experienced various kinds of dynamics, such as conflicts and so on. But in the end, it got a responsive reaction from all circles, because in principle, the existence of the fatwa is an essential form of alternatives and solutions in creating a more progressive, realistic, dynamic, and contextualist religious and religious pattern, which at the same time displays the face of Islamic Law which is rahmatan lil. alamin sholihul likulli wal eat.

\section{Keywords: Dynamics, Existence, MUI Fatwa, Covid-19}

\section{A. PENDAhULUAN}

Mewabahnya pandemi virus covid-19 diseluruh dunia, tentu saja berpengaruh sekaligus berimplikasi pada setiap sektor lini kehidupan manusia, tidak terkecuali bagi mayoritas umat muslim di Indonesia. Dimana interelasi diantara keduanya (Syariat dan Covid-19) bermuara pada pada persoalan tatanan dan penyelenggaraan ibadah dan tipologi penularan virus tersebut. Sebagaimana yang dilansir melalui statement WHO atau Kemenkes RI bahwa proses penyebaran virus adalah melalui percikan droplet pada saat bersin, melalui intensitas kontak fisik antara seorang pasien penderita corona terhadap orang lainnya, bahkan dikatakan bahwa penularan dapat terjadi melalui benda-benda yang telah tercemar virus, bekas sentuhan dari penderita. Ironisnya virus ini tidak mudah untuk dideteksi karena memiliki masa inkubasi dengan perkiraan rentang waktu 14 hari paling sedikit. Sehingganya, mau tidak mau langkah praktis yang harus diambil oleh seluruh pihak medis, sebagai alternative darurat adalah himbauan untuk untuk melakukan Physical distancing sebagai satu-satunya 
solusi terbaik ketika vaksin masih belum ditemukan, dengan tujuan agar dapat memutus rantai penyebaran virus. ${ }^{1}$

Hal ini tentu saja berbanding terbalik dengan tata cara pelaksanaan ibadah umat Islam yang sangat potensial dengan kerumunan (jamaah) hingga kontak fisik, dalam doktrin keagamaan yang mengalir dalam sejarah islam, berjamaah merupakan suatu hal yang tidak akan pernah terlepaskan sebagai bagian pokok dari wujud eksistensi umat muslim itu sendiri. Sebut saja sholat yang dikerjakan sendirian tidak lebih baik dari sholat yang dilaksanakan berjamaah, dan sholat berjamaah di rumah tidak lebih baik dari sholat berjamaah yang dilaksanakan di masjid, atau misalnya tentang tata pelaksanaan sholat jumat. Tidak heran dengan kemunculan pandemi ini telah memantik berbagai macam dilematika bagi umat muslim, bahkan telah diprediksi akan melahirkan benturan-benturan pemahaman teks dan realitas yang tidak bisa dihindari. Artinya akan ada gesekan antara kalangan konservatif yang begitu mengkultuskan teks-teks suci untuk mendudukan ibadah berjamaah, dengan satu kalangan yang cenderung fleksibel dalam menghayati nilai-nilai ajaran islam melalui pertimbangan teks dan kontekstualisasi demi meneguhkan visi kemaslahatan.

Kehadiran Majelis Ulama Indonesia bukanlah sebuah kebetulan, melainkan sebagai lembaga yang mewadahi Alim Ulama, Zu'ama, dan cendikiawan Islam diseluruh indonesia untuk membimbing, membina dan mengayomi umat termasuk dalam merekayasa piranti positif dalam bentuk diktum keagamaan untuk meneguhkan Maqosid as-Syariah. MUI sangat menyadari bahwa tanggung jawab kebaikan umat adalah tugas pokok yang lazim untuk diwujudkan sebagai bagian dari eksistensi dan perananya selaku Khadim al-Ummah, hal ini tidak cukup hanya sekedar menunaikan ataupun sekedar memberikan sokongan dalam bentuk dukungan spiritual dan moral saja, melainkan juga layanan yang lebih prima bagi umat terutama dalam upaya bersama melawan pencegahan penyebaran wabah virus corona yang kian hari semakin mengkhawatirkan dalam bentuk Fatwa.

\footnotetext{
${ }^{1}$ Faried F. Saenong, Dkk, Fikih Pandemi Beribadah Di Masa Wabah, (Jakarta: Percetakan Gaya Media Pratama, 2020). Hlm. 6.
} 


\section{B. METODE PENELITIAN}

Penelitian ini didesain dalam bentuk penelitian (Library Reserach) menggunakan berbagai sumber kepustakaan sebagai sumber data penelitian, dengan tujuan menelisik dan mengupas nilai-nilai eksistensi Fatwa MUI dalam upaya memitigasi Covid-19 yang jauh hari kian merajalela. Penelitian ini juga mengaplikasikan pendekatan deskriptif-normatif karena ditujukan untuk mendiskripsikan pandemi dan keberadaan Fatwa sebagai sebuah fenomena nyata, yang melahirkan beragam dinamika dan respon sosial masyarakat, serta berangkat dari bangunan sumber data primer dan sekunder sebagai pendukung. Dari data yang terkumpulkan melalui dokumen-dokumen yang interkorelatif dan tinjuan terhadap realita sosial di tengah masyarakat penulis berusaha menganalisisnya melalui proses Descriptive Analytic Method Content sebagai pisau analisis. ${ }^{2}$ Adapun pengambilan kesimpulan dilakukan dengan cara mengaplikasikan metode berpikir induktif (menarik kesimpulan dari hal-hal yang bersifat khusus menjadi umum) dan deduktif (menarik kesimpulan dari hal-hal umum menjadi khusus). ${ }^{3}$

\section{PEMBAHASAN}

\section{Sekilas Tentang Majelis Ulama Indonesia}

MUI adalah wadah silaturahmi ulama, zu'ama dan cendikiawan muslim Indonesia untuk menyatukan gerak dan langkah umat Islam dalam mewujudkan kesatuan dan persatuan umat dalam rangka menyukseskan pembangunan serta ketahanan nasional Republik Indonesia. Selama rentang waktu 40 tahun sejak lahirnya MUI pada tahun 1975, MUI sebagai lembaga penghimpun para ulama merupakan penerus tugas-tugas para Nabi (Warasatul

\footnotetext{
${ }^{2}$ Metode kajian isi merupakan teknik yang paling banyak dipakai untuk untuk memanfaatkan dokumen yang padat isinya. Artinya kajian isi digunakakan sebagai teknik penelitian untuk keperluan mendeskripsikan secara objektif, sistematis dan kuantitatif tentang menifestasi komunikasi yang memanfaatkan seperangkat prosedur untuk menarik kesimpulan yang shahih dari buku, jurnal, penelitian, atau dokumen-dokumen yang berkaitan dengan focus penelitian. Lihat Hendriyani, “Analisis Isi: Sebuah Pengantar Metodologi Yang Mendalam dan Kaya Dengan Contoh, ” Jurnal Komunikasi Indonesia 2, no. 1 (2017): hlm. 63-65.

${ }^{3}$ Noeng Muhajir, Metodologi Penelitian Kuantitatif, (Yogyakarta: Percetakan Raka Sarasin, 2016). Hlm. 76-77.
} 
TAHKIM, Jurnal Peradaban dan Hukum Islam. Vol.3 No.2 (0ktober, 2020) | ISSN : 2597-7962

Anbiya) dan concern terhadap kesejahteraan rohani umat, tentunya telah banyak menghasilkan produk berwujud fatwa-fatwa yang membahas berbagai dimensi kehidupan masyarakat. MUI telah menerbitkan berbagai macam fatwa dalam masalah ibadah, hukum, sosial, politik, politik, etika dan bahkan juga ekonomi.

Adapun visi yang diemban oleh Majelis Ulama Indonesia adalah: "Terciptanya kondisi kehidupan kemasyarakatan, kebangsaan dan kenegaraan yang baik sebagai hasil penggalangan potensi dan partisipasi umat Islam melalui aktualisasi potensi ulama, zu'ama, aghniya dan cendikiawan muslim untuk kejayaan Islam dan umat Islam (Izzu Al-Islam Wa Al-Muslimin) guna perwujudannya. Dengan demikian posisi Majelis Ulama Indonesia adalah berfungsi sebagai Dewan Pertimbangan Syari'at Nasional, guna mewujudkan Islam yang penuh rahmat (Rahmat Li Al-'Alamin) di tengah kehidupan umat manusia dan masyarakat Indonesia. Sementara misi yang diemban oleh Majelis Ulama Indonesia adalah: "Menggerakkan kepemimpinan dan kelembagaan Islam sevara efektif, sehingga mampu mengarahkan dan membina umat Islam dalam menanamkan dan memupuk aqidah Islamiyah, dan menjadikan ulama sebagai panutan dalam mengembangkan akhlak karimah agar terwujud masyarakat yang khair al-ummah. "4

Dilihat dari latar belakang sejarahnya, pendirian MUI merupakan hasil dari proses panjang dari tarik menarik antara hubungan agama dan negara yang direpresentasikan oleh kelompok ulama dan kelompok sekular nasionalis, juga adanya kepentingan pemeritah kepada umat Islam. Salah satu tugasnya, MUI diharapkan melaksankan tugasnya dalam pemberian fatwa-fatwa dan nasihat, baik kepada Pemerintah maupun kepada kaum muslimin mengenai persoalan- persoalan yang berkaitan dengan keagamaan khususnya dan semua masalah yang dihadapi bangsa umumnya. Sehubungan dengan berbagai amanat baik dari kepala negara ataupun sejumlah menteri serta pemikiran dan saran dari peserta musyawarah

${ }^{4}$ Asrorun Ni'am Soleh, Metodologi Penetapan Fatwa Majelis Ulama Indonesia, (Jakarta: Percetakan Emir, 2016). Hlm. 32. 
TAHKIM, Jurnal Peradaban dan Hukum Islam. Vol.3 No.2 (0ktober, 2020) | ISSN : 2597-7962

maka Munas I MUI telah telah merumuskan dalam pasal 4 pedoman pokoknya yang menyebutkan bahwa MUI berfungsi:

a. Memberi fatwa dan nasehat mengenai masalah keagamaan dan kemasyarakatan kepada pemerintah dan umat Islam umumnya sebagai amal ma'ruf nahi munka, dalam usaha meningkatkan ketahanan nasional.

b. Memperkuat ukhuwah Islamiyah dan melaksanakan kerukunan antar umat beragama dalam mewujudkan persatuan dan kesatuan nasional.

c. Mewakili umat Islam dalam konsultasi antar umat beragama.

d. Penghubung ulama dan umara (pemerintah) serta jadi penerjemah timbal balik antara pemerintah dan umat guna menyukseskan pembangunan nasional.

e. Majelis Ulama tidak berpolitik dan tidak operasional.

Untuk mencapai tujuannya, Majelis Ulama Indonesia melaksanakan usaha-usaha :

1) Memberikan bimbingan dan tuntutan kepada umat Islam dalam mewujudkan kehidupan beragama dan bermasyarakat yang diridhoi oleh Allah Swt.

2) Memberikan nasehat dan fatwa mengenai masalah keagamaan dan kemasyarakat kepada pemerintah dan masyarakat.

3) Meningkatkan kegiatan bagi terwujudnya ukhuwah Islamiyah dan kerukunan antar umat beragama dalam memantapkan kesatuan dan persatuan bangsa.

4) Menjadi penghubung antara ulama dan umara (pemerintah) dan penterjemah timbal balik antara pemerintah dan umat guna mensukseskan pembangunan nasional.

5) Meningkatkan hubungan serta kerjasama antara berbagai organisasi, lembaga Islam, dan cendikiawan muslim.

6) Mewakili umat Islam dalam hubungan dan konsultasi antar umat beragama.

7) Usaha lainnya yang sesuai dengan tujuan organisasi. ${ }^{5}$

\footnotetext{
${ }^{5}$ Tim Penyusun, Fatwa Majelis Ulama Indonesia (MUI) Dalam Perspektif Hukum Dan PerundangUndangan (Jakarta: Puslitbang Kehidupan Keagamaan Badan Litbang dan Diklat Kementerian Agama RI, 2012). Hlm. 44.
} 
TAHKIM, Jurnal Peradaban dan Hukum Islam. Vol.3 No.2 (0ktober, 2020) | ISSN : 2597-7962

\section{Aransemen Seputar Fatwa}

\section{a) Definisi Fatwa}

Fatwa menurut bahasa berarti jawaban mengenai suatu kejadian (peristiwa), yang merupakan bentukan sebagaimana dikatakan Zamakhsyarin dalam Al-Kasysyaf dari kata (alfataa/pemuda) dalam usianya, dan sebagai kata kiasan (metafora) atau (Isti'arah). Sedangkan pengertian fatwa menurut syara' adalah menerangkan hukum syara' dalam suatu persoalan sebagai jawaban dari suatu pertanyaan, baik si penanya itu jelas identitasnya maupun tidak, baik perseorangan maupun kolektif. Definisi fatwa menurut Kamus Besar Bahasa Indonesia yaitu: (1) jawaban berupa keputusan atau pendapat yang diberikan oleh mufti/ahli tentang suatu masalah; dan (2) nasihat orang alim; pelajaran baik; dan petuah.Fatwa adalah jawaban resmi terhadap pertanyaan dan persoalan yang menyangkut masalah hukum. Fatwa berasal dari kata bahasa arab alifta', al-fatwa yang secara sederhana berarti pemberian keputusan. Fatwa bukanlah sebuah keputusan hukum yang dibuat dengan gampang, atau yang disebut dengan membuat hukum tanpa dasar. ${ }^{6}$

Menurut Imam Ibnu Mandzur di dalam lisan al-arab menyatakan, Aftaahu Fi Al-Amr Abaanahu Lahu (menyampaikan fatwa kepada dia pada suatu perkara, maksudnya adalah menjelaskan perkara tersebut kepadanya). Wa Aftaa Al-Rajulu Fi Al-Mas'alah (seorang lakilaki menyampaikan fatwa pada suatu masalah). Wa Astaftainuhu Fiiha Fa Aftaaniy Iftaa'an Wa Futaa (aku meminta fatwa kepadanya dalam masalah tersebut, dan dia memberikan kepadaku sebuah fatwa)". Perkataan Wafataay adalah asal dari kata futya atau fatway. Futya dan fatwa adalah dua isim (kata benda) yang digunakan dengan makna al-iftaa'. Iftaa' berasal dari kata Iftaay, yang artinya memberikan penjelasan. Secara normatif memang sedikit sulit merumuskan tentang arti ifta' atau berfatwa itu. Namun dari penjelasan diatas dapatlah disimpulkan, yaitu: suatu usaha memberikan penjelasan tentang hukum syara' oleh ahlinya kepada orang yang belum mengetahui”. Di dalam kitab Mafaahim Islamiyyah

\footnotetext{
${ }^{6}$ Iswahyudi, "MUI Dan Nalar Fatwa-Fatwa Eksklusif," Al-Ihkam: Jurnal Hukum \& Pranata Sosial 11, no. 2 (2017). Hlm. 34-40.
} 
dijelaskan bahwa, secara literal, kata "Fatwa" bermakna" jawaban atas persoalan-persoalan syariat atau perundang-undangan yang sulit. Bentuk jamaknya adalah Fataawin atau Fataaway. Jika dinyatakan Aftay Fi Al-Mas'alah menjelaskan tentang hukum dalam masalah tersebut. $^{7}$

Sedangkan Al Iftaa' adalah sebuah penjelasan hukum yang berkaitan dengan persoalan syariat, undang-undang, atau semua hal yang berkaitan dengan pertanyaan orang yang bertanya (Ibaanat Al-Ahkaam Fi Al-Mas'alah Al Syar'iyyah, Au Qanuuniyyah, Au Ghairihaa Mimmaa Yata'allaqu Bisu'aal Al-Saail). Sedangkan Muftiy adalah seseorang yang memiliki kualifikasi untuk dapat memberikan penjelasan hukum atau menyampaikan fatwa ditengahtengah masyarakat. Menurut pengertian syariat, tidak ada perselisihan pendapat mengenai makna syariat dari kata al-fatwa dan al-iftaa' berdasarkan makna bahasa. Menurut Yusuf alQardhawi, Fatwa ialah suatu upaya untuk menjelaskan Hukum Syara' dalam suatu masalah sebagai bentuk jawaban atas pertanyaan yang diajukan oleh peminta Fatwa (Mustafi) baik permintaan tersebut dilakukan secara perorangan ataupun secara kolektif, demikian selaras dengan pendapat Quraish Shihab, yang mendefinisikan fatwa sebagai petuah, nasihat, atau jawaban dari pertanyaan hukum dalam ajaran Islam. Menurut Amir Syarifuddin, fatwa atau ifta' berasal dari kata afta, yang berarti memberi penjelasan. Secara definitif fatwa yaitu usaha memberikan penjelasan tentang hukum syara' oleh ahlinya kepada orang yang belum mengetahuinya. Dari pengertian di atas dapat disimpulkan bahwa fatwa adalah hasil ijtihad seorang mufti sehubungan dengan peristiwa hukum yang diajukan kepadanya. Jadi fatwa lebih khusus dari pada fikih atau ijtihad secara umum. Karena boleh jadi fatwa yang dikeluarkan seorang mufti, sudah dirumuskan dalam fikih, hanya belum dipahami oleh peminta fatwa. ${ }^{8}$

7 Abdul Wasik and Muhammad Muhammad, "Dasar Fatwa MUI Dalam Penerapan Hukum Islam (Telaah atas Interaksi Sosial dalam Perkembangan Hukum Islam di Indonesia), Jurnal Kajian Hukum Islam dan Pemikiran" 2018, hlm. 933-55.

${ }^{8}$ Muhammad Yusuf, "Pendekatan Al-Mașlahạh Al-Mursalah dalam Fatwa MUI Tentang Pernikahan Beda Agama, ” Jurnal Ahkam: Jurnal Ilmu Syariah 13, no. 1 (2013): hlm. 99-108. 


\section{b) Landasan Dasar Hukum Fatwa}

Adapun landasan Hukum fatwa, terdapat dalam Al-Quran dan Hadist Berikut:

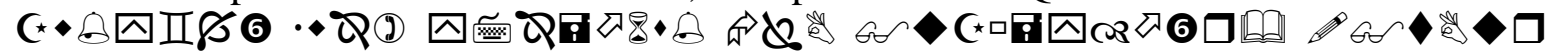

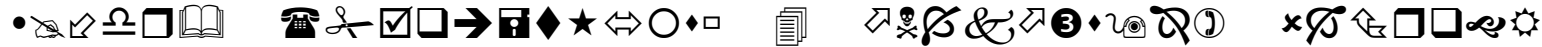

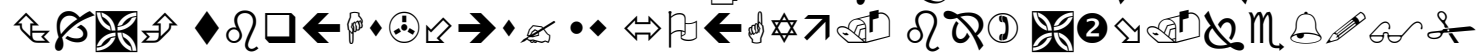

Terjemahnya: dan Kami tidak mengutus sebelum kamu, kecuali orang-orang lelaki yang Kami beri wahyu kepada mereka; Maka bertanyalah kepada orang yang mempunyai pengetahuan [Yakni: orang-orang yang mempunyai pengetahuan tentang Nabi dan kitabkitab] jika kamu tidak mengetahui (An-Nahl: 43)

Dari ibnu abbas r.a. bahwa Sa'ad Bin 'Ubadah r.a. Minta Fatwa kepada Nabi SAW, yaitu dia mengatakan; sesungguhnya ibuku meninggal dunia padahal beliau mempunyai kewajiban nadzar yang belum ditunaikanya? Lalu Rasulullah SAW. Menjawab: "tunaikan nadzar itu atas nama ibumu". (HR Abu daud dan Nasai). ${ }^{9}$

\section{c) Sekilas tentang Mufti dan Syaratnya}

Mufti (berkedudukan sebagai pemberi penjelas tentang hukum syara' yang harus di ketahui dan diamalkan oleh umat. Umat akan selamat bila ia memberi fatwa yang benar dan akan sesat bila ia salah dalam berfatwa, ia harus memiliki syarat-syarat sebagai berikut:

a. Syarat umum. Ia harus seorang mukallaf yaitu muslim, dewasa, dan sempurna akalnya.

b. Syarat-syarat kepribadian yaitu adil, dapat dipercaya, dan mempunyai moralitas. Syarat ini harus dimiliki seorang mufti karena ia secara langsung akan menjadi panutan masyarakat.

c. Syarat keilmuan. Ia harus ahli dan mempunyai kemampuan untuk berijtihad, seperti pengetahuan bahasa, pengetahuan al-Qur'an dan Sunnah Nabi, ijma', dan pengetahuan ushul fiqh, dan tujuan hukum.

d. Syarat pelengkap. Ia harus mempunyai keteguhan niat, tenang jiwanya, hasil fatwanya tidak membingungkan atau menimbulkan kontroversi dan dikenal di tengah umat. ${ }^{10}$

\footnotetext{
${ }^{9}$ Makruf Amin, Fatwa Dalam Kacamata Hukum Islam (Jakarta: Percetakan ElsaS, 2000). Hlm. 23.

10 Abdul Fatah Idris, Menggugat Istinbath Hukum Ibnu Qayyim Studi Kritik Terhadap Metode Penetapan Hukum Ibnu Qayyim Al-Jauziyah (Semarang: Percetakan Pustaka Zaman, 2007). Hlm. 22.
} 


\section{Metodologi dan Tekhnis Penetapan Fatwa MUI}

Metodologi dalam penetapan Fatwa merupakan salah satu komponen yang sangat penting dari segi kedudukan dan juga fungsinya sebagai roh eksistensi MUI dalam menjalankan kesinambungannya untuk melahirkan kemaslahatan kepada umat. Adapun metode yang diaplikasikan oleh Komisi Fatwa MUI dalam proses penetapan fatwa dilakukan melalui tiga pendekatan integral, yaitu 1) Pendekatan Nash Qath 'i, 2) Pendekatan Qauli dan 3) Pendekatan Manhaji. Pendekatan Nash Qath'i dilakukan dengan berpegang kepada dalildalil al-Qur'an atau Hadis untuk sesuatu problematika apabila masalah yang ditetapkan terdapat dalam nash al-Qur'an ataupun Hadis secara jelas. Namun bilamana tidak terdapat dalam nash al-Qur'an maupun Hadis maka tekhnis penjawaban harus dilakukan dengan metode pendekatan Qauli dan Manhaji. Pendekatan Qauli adalah pendekatan dalam proses penetapan fatwa dengan mendasarkannya pada pendapat para Imam Mazhab dalam kitabkitab fiqih terkemuka (Al-Kutub Al-Mu'tabarah). Pendekatan Qauli dilakukan apabila jawaban dapat dicukupi oleh pendapat dalam kitab-kitab fiqih terkemuka (Al-Kutub AlMu'tabarah) dan hanya terdapat satu pendapat, kecuali jika pendapat yang ada dianggap tidak cocok lagi untuk dipegangi karena sangat sulit untuk dilaksanakan (Ta'assur Atau Ta'adzdzur Al-'Amal Atau Shu'ubah Al-'Amal), atau karena alasan hukumnya ('illah) berubah. Dalam kondisi seperti ini perlu dilakukan telaah ulang (I'adatun Nazhar), sebagaimana yang dilakukan oleh ulama terdahulu. Karena itu mereka tidak terpaku terhadap pendapat ulama terdahulu yang telah ada bila pendapat tersebut sudah tidak memadai lagi untuk didijadikan pedoman. ${ }^{11}$

Apabila jawaban permasalahan tersebut tidak dapat dicukupi oleh nash Qoth ' $i$ dan juga tidak dapat dicukupi oleh pendapat yang ada dalam kitab-kitab fiqih terkemuka (Al-Kutub Al-Mu'tabarah), maka proses penetapan fatwa dilakukan melalui pendekatan manhaji. Pendekatan Manhaji adalah pendekatan dalam proses penetapan fatwa dengan

\footnotetext{
${ }^{11}$ Jaih Mubarok, “Dinamika Fatwa Produk Keuangan Syariah,” Ijtihad : Jurnal Wacana Hukum Islam Dan Kemanusiaan 13, no. 1 (2013). Hlm.32.
} 
mempergunakan kaidah-kaidah pokok (Al-Qowaid Al-Ushuliyah) dan metodologi yang dikembangkan oleh imam mazhab dalam merumuskan hukum suatu masalah. Pendekatan manhaji dilakukan melalui ijtihad secara kolektif (ijtihad jama'i), dengan menggunakan metode: mempertemukan pendapat yang berbeda (al-Jam'u wat taufiq), memilih pendapat yang lebih akurat dalilnya (tarjihi), menganalogkan permasalahan yang muncul dengan permasalahan yang telah ditetapkan hukumnya dalam kitab-kitab fiqh (Ilhaqi) dan Istinbathi. Dalam persoalan didalamnya terdapat khilafiyah di kalangan imam mazhab maka penetapan fatwa didasarkan pada hasil usaha penemuan titik temu di antara pendapat-pendapat madzhab melalui metode Al-Jam'u Wa Al-Taufiq. ${ }^{12}$

Jika usaha Al-Jam'u Wa Al-Taufiq tidak berhasil maka penetapan fatwa dilakukan melalui metode Tarjih (memilih pendapat ulama yang dinilai paling kuat dalil dan argumentasinya), yaitu dengan menggunakan metode perbandingan mazhab (muqaran almadzahib) dan dengan menggunakan kaedah-kaedah ushul fiqh perbandingan. Bersikap abai terhadap masyarakat untuk menentukan sendiri pendapat ulama yang akan dipilih sangatlah ironi dan beresiko, pasalnya hel tersebut mengindikasikan sikap ketidak pedulian terhadap kemaslahatan umat, terlebih jika pilihan pendapat (Qaul) ulama yang instimbathnya tanpa melalui prosedur kumulatif, batasan dan patokan. Oleh karena itu, menjadi lazim bagi lembaga fatwa yang memiliki kompetensi untuk memilih pendapat (Qaul) yang rajih (lebih kuat dalil dan argumentasinya) untuk dijadikan pedoman bagi masyarakat. Ketika satu masalah atau satu kasus belum ada pendapat (qaul) yang menjelaskan secara persis dalam kitab fiqh terdahulu (Al-Kutub Al-Mu'tabarah) namun terdapat padanannya dari masalah tersebut, maka penjawabannya dilakukan melalui metode ilhaqi, yaitu menyamakan suatu masalah yang terjadi dengan kasus padanannya dalam al-kutub al-mu'tabarah. ${ }^{13}$

${ }^{12}$ Barlinti Salma Yeni, Kedudukan Fatwa Dewan Syariah Naional Dalam Sistem Hukum Nasional Di Indonesia (Jakarta: Badan Litbang dan Diklat Kementerian Agama Republik Indonesia, 2010). Hlm. 74.

${ }^{13}$ Mohamad Atho Mudzhar and Khoirudin Nasution, "Hukum Keluarga Di Dunia Islam Modern," Mimbar Hukum 12 (1994). Hlm. 26. 
TAHKIM, Jurnal Peradaban dan Hukum Islam. Vol.3 No.2 (0ktober, 2020) | ISSN : 2597-7962

Sedangkan metode Istinbathi dilaksanakan ketika tidak bisa dilakukan dengan metode ilhaqi karena tidak ada padanan pendapat (Mulhaq Bih) dalam Al-Kutub Al-Mu'tabarah. Metode istinbathi dilakukan dengan memberlakukan metode Qiyasi, Istishlahi, Istihsani dan Sadd Al-Dzari'ah. Secara umum penetapan fatwa di MUI selalu memperhatikan pula kemaslahatan umum (Mashalih 'Ammah) dan intisari ajaran agama (Maqashid Al-Syari'ah). Sehingga fatwa yang dikeluarkan oleh MUI benar-benar bisa menjawab permasalahan yang dihadapi umat dan benar-benar dapat menjadi alternatif pilihan umat untuk dapat menjadi pedoman.

\section{Fatwa MUI di Masa Pandemi: Dinamika, Karakteristik, dan Respon Sosial}

Covid-19 merupakan problematika global yang dihadapi seluruh masyarakat dunia, alasan ini tidak berlebihan mengingat persoalan pandemi yang menyentuh tatanan kelangsungan hidup umat manusia. Sejak dirilis oleh World Healt Organization (WHO) pada 11 Februari 2020 hingga saat ini, tercatat covid-19 telah merenggut 773.000 nyawa diseluruh dunia. Pemerintah merespon penyebaran virus tersebut dengan melakukan berbagai macam kebijakan demi menekan angka kematian dan memutus rantai penularan, oleh karena itu pemerintah berusaha mensinergikan diri dengan MUI sebagai pemegang otoritas keagamaan yang berpengaruh di Indonesia, mengingat Islam merupakan agama mayoritas yang dipeluk oleh sebagian besar warga Indonesia, terlebih sebagaimana yang dijelaskan pada bagian pendahuluan, bahwa interelasi mode penyebaran virus ini sangat potensial terhadap tatacara pelaksanaan ibadah umat muslim. Sejauh ini sejak pertama kali kemuculan pandemi virus covid-19 hingga saat ini (New Normal) MUI telah banyak memberikan kontribusi positif dalam membangun nilai kemaslahatan untuk umat melalui fatwa, diantaranya:

a) Fatwa MUI Nomor 14 Tahun 2020 Tentang Penyelenggaraan Ibadah Dalam Situasi Terjadi Wabah Covid-19.

b) Fatwa Nomor 17 Tahun 2020: Pedoman Kaifiat Shalat Bagi Tenaga Kesehatan Yang Memakai Alat Pelindung Diri (APD) Saat Merawat dan Menangani Pasien Covid-19. 
TAHKIM, Jurnal Peradaban dan Hukum Islam. Vol.3 No.2 (0ktober, 2020) | ISSN : 2597-7962

c) Fatwa Nomor 18 Tahun 2020: Pedoman Pengurusan Jenazah (Tajhiz Al-Jana 'iz) Muslim Yang Terinfeksi Covid-19.

d) Fatwa Nomor 23 Tahun 2020: Pemanfaatan Harta Zakat, Infak, dan Shadaqah untuk Penanggulangan Wabah Covid-19 dan Dampaknya.

e) Fatwa Mui Nomor 28 Tahun 2020 Tentang Panduan Kaifiat Takbir dan Shalat Idul Fitri Saat Covid 19.

f) Fatwa Mui Nomor 31 Tahun 2020 Tentang Penyelenggaraan Shalat Jumat dan Jamaah Untuk Mencegah Penularan Covid-19.

g) Fatwa Mui Nomor 36 Tentang Shalat Idul Adha dan Penyembelihan Hewan Kurban Saat Wabah Covid-19.

Sejak dikeluarkannya Fatwa No 14 Tahun 2020 pada 16 Maret 2020, ketika wabah virus corona telah mulai menyebar di Indonesia. Telah memantik berbagai macam kontroversi dan menuai banyak kritikan dari beragam kalangan masyarakat, hingga fatwa ini dianggap sebagai fatwa yang paling booming di masa wabah virus corona merajalela. Pasalnya bagi sebagian besar masyarakat muslim yang awam berasumsi bahwa Fatwa ini cenderung menerabas konsep-konsep dan tatanan aturan peribadahan yang selama ini telah mengkristal sebagai suatu dogma yang tidak bisa diganggu gugat lagi, oleh karena itu dalam persoalan ini, volume atau tingkat pemahaman umat tentang persoalan ibadah menjadi tolak ukur efektifitasnya fatwa diatas, terlebih pada dasarnya masyarakat muslim di indonesia banyak yang masih memiliki pola paradigma teodisi, fatalistic, dan determinan dalam beragama, misalnya dalam ketentuan poin ke-(4) yaitu: Dalam kondisi penyebaran Covid-19 tidak terkendali di suatu kawasan yang mengancam jiwa, umat Islam tidak boleh menyelenggarakan shalat jumat di kawasan tersebut, sampai keadaan menjadi normal kembali dan wajib menggantikannya dengan shalat zuhur di tempat masing-masing. Demikian juga tidak boleh menyelenggarakan aktifitas ibadah yang melibatkan orang banyak dan diyakini dapat menjadi media penyebaran Covid-19, seperti jamaah shalat lima 
TAHKIM, Jurnal Peradaban dan Hukum Islam. Vol.3 No.2 (0ktober, 2020) | ISSN : 2597-7962

waktu/rawatib, shalat Tarawih dan Ied di masjid atau tempat umum lainnya, serta menghadiri pengajian umum dan majelis taklim.

Ketentuan sebagaimana yang dijelaskan diatas tentu saja banyak menuai sikap pro dan kontra di sebagian besar masyarakat, hal ini menjadi lumrah terlebih fatwa dibaca dengan kacamata hitam putih tanpa melalui gugatan interpretasi yang terinterkorelasi antara satu item dengan yang lainnya, artinya pada dasarnya fatwa No 14 tahun 2020 terdiri dari 9 diktum yang merupakan sebuah kesatuan yang perlu ditelaah secara keseluruhan. Kesalahpahaman dan parsialitas paradigma masyarakat menjadikan fatwa seolah-olah adalah suatu larangan yang kesannya cenderung dibuat-buat oleh MUI, apalagi ditambah dengan hembusan penggiringan opini bahwa covid-19 adalah sebuah konspirasi yang dilakukan pemerintah untuk mendapatkan keuntungan dalam hal-hal tertentu. Lain halnya sebagaimana kasus cluster terbesar di Sulawesi Selatan Gowa pada kegiatan Muzakarah Jamaah Tabligh seluruh asia, sangat nampak bahwa asumsi para Jamaah tentang virus corona adalah semacam pandemi yang sama sekali tidak akan berbahaya bagi mereka, hingga dalam tabligh mereka tidak heran mendengaungkan jargon "Jangan takut corona tapi takutlah kepada Allah". Padahal dalam agama sangat jelas bagaimana umat, dituntut untuk harus menjaga keseimbangan antara menjaga aktivitas keagamaan sesuai tuntunan syariat dengan menjaga keselamatan jiwa, lagi-lagi problematika tersebut diakibatkan oleh upaya sosialisasi yang pada saat itu masih kurang maksimal dan pengetahuan yang minim tentang virus corona. Oleh karena itu pemerintah (para medis yang memiliki otoritas dan wewenang dalam persoalan kesehatan), sangat menekankan sinergitas peranan sentral MUI melalui fatwanya untuk kemudian memanfaatkan seluruh stakeholder terkait. Demi upaya mitigasi penyebaran virus corona yang semakin merajalela.

Namun seiring berjalannya waktu, masyarakat semakin responsif dan lebih bijak dalam melihat fatwa, tidak menggunakan kacamata normatif lagi, masyarakat semakin terbuka sekaligus mengimplementasikan nilai-nilai fleksibilitas fatwa hingga pada saat new normal dengan Fatwa Mui terakhir Nomor 36 Tentang Shalat Idul Adha dan Penyembelihan 
Hewan Kurban Saat Wabah Covid-19. Masyarakat semakin lebih realistis dan memahami pentingnya internalisasi keagamaan dengan menjunjung tinggi semangat kontekstualitas dan teks yang relevan dengan realita yang ada. Hingga semangat keberagamaan tersebut akan selaras dengan semangat untuk membekali diri dengan ilmu pengetahuan terhadap agama itu sendiri. Bagaimanapun respon positif tersebut bukanlah tidak beralasan, selain dari upaya segenap elemen masyarakat untuk mengevaluasi dan mengaktualisasikan diri menyangkut persoalan fatwa. Pada hakikatnya corak dan karakteristik fatwa-pun sangat mudah dan rasional untuk dapat diterima oleh semua kalangan, beberapa alasannya: 1) Fatwa berdasarkan pada Al-Quran, Hadist, Ijma', ${ }^{14}$ Qiyas, ${ }^{15}$ dan dalil lain yang Mu'tabar. 2) Pada tatanan proses penetapan fatwa bersifat responsif, proaktif dan antisipatif. 3) Fatwa yang telah ditetapkan mengusung prinsip argumentatif (memiliki kekuatan hujjah), legitimatif (menjamin penilaian keabsahan hukum), kontekstual (Waqi’iy), aplikatif (siap diterapkan), dan moderat. 4) Dalam proses penetapan, akan dilakukan terlebih dahulu kajian komprehensif ${ }^{16}$ untuk dapat memperoleh deskripsi utuh tentang obyek masalah (tashawwur al-masalah), rumusan masalah, termasuk implikasi sosial keagamaan yang ditimbulkan dan titik kritis dari berbagai aspek hukum (Norma Syari'ah) yang bertalian dengan problematika tersebut. 5) Penetapan fatwa terhadap masalah yang telah jelas hukum dan dalil-dalilnya (Ma'lum Min Al-Din Bi Al-Dlarurah) dilakukan dengan menyampaikan hukum sebagaimana apa adanya. 6) Penetapan fatwa terhadap masalah yang terjadi perbedaan pendapat (Masail Khilafiyah) di kalangan madzhab, maka didasarkan pada hasil Al-Jam'u Wa Al-Taufiq, namun jika tidak tercapai titik temu antara pendapat- pendapat tersebut, penetapan fatwa

\footnotetext{
${ }^{14}$ Ijma' adalah kesepakatan para ulama mujtahidin masa lalu tentang suatu masalah agama. Lihat Pedoman Penetapan Fatwa Majelis Ulama Indonesia, Ditetapkan di : Jakarta, Pada Tanggal : 1 Juni 2012 oleh Dewan Pimpinan Majelis Ulama Indonesia, Ketua Umum Ma'ruf Amin.

${ }^{15}$ Qiyas adalah pemberlakuan hukum sesuatu yang disebutkan dalam nash Al-Qur'an atau Hadis kepada sesuatu yang tidak disebutkan hukumnya oleh nash karena kesatuan illat hukum di antara keduanya. Lihat. Ibid.

${ }^{16}$ Kajian komprehensif dimaksud adalah mencakup telaah atas pandangan fuqaha mujtahid masa lalu, pendapat para imam madzhab danulama yang mu'tabar, telaah atas fatwa-fatwa yang terkait, serta pandangan ahli fikih terkait masalah yang akan difatwakan.
} 
TAHKIM, Jurnal Peradaban dan Hukum Islam. Vol.3 No.2 (0ktober, 2020) | ISSN : 2597-7962

didasarkan pada hasil Tarjih melalui metode Muqaranah (perbandingan) dengan menggunakan kaidah-kaidah ushul fiqih Muqaran. Sedangkan terhadap masalah yang tidak ditemukan pendapat hukum di kalangan Madzhabatau ulama yang Mu'tabar, yang dilandaskan pada ijtihad kolektif melalui metode bayani dan Ta'lili (Qiyasi, Istihsaniy, Ilhaqiy, Istihsaniy, dan Sad Al-Dzaraa'i) Serta metode penetapan hukum (manhaj) yang dipedomani oleh para ulama madzhab.

Dominasi dan hegemoni pengaruh MUI sebagai pemegang otoritas kewenangan dalam persoalan agama yang legal (dibawah kendali pemenrintah), dalam persoalan penyelenggaraan ibadah di masa pandemi dibangun berdasarkan dua model, 1) Dominasi pada legal dengan indikasi bahwa fatwa telah melalui konsolidasi, komunikasi, dan kerja sama dengan pemerintah pusat. 2) Dominasi kekuatan pengaruh dan kekuasaan kharismatik MUI sendiri sebagai lembaga keagamaan yang memayungi banyak ormas Islam di Indonesia. Setali tiga uang secara literal, motif fatwa MUI yang diterbitkan pada masa pandemi memiliki tiga unsur motif dominan, yaitu, 1) Value traditional, MUI berusaha melanjutkan tata cara Nabi dan para Sahabat dalam memitigasi wabah (tha'un), sehingga tiplogi pelaksanaan peribadatan yang MUI anjurkan menggunakan pendekatan hermeneutis sebagaimana yang dilakukan Nabi. 2) Value Rational MUI menggunakan nilai-nilai dari Agama Islam yang bersumber dari Alquran, Hadis, Ijma, Qiyas, dan Kaidah Fikih yang bersifat rasional-dinamis dan sarat akan probabilitas sehingga melahirkan alternatif-alternatif peribadatan yang dapat dijadikan sebagai mitigasi wabah Covid-19, dan 3) instrumentally rational diman fatwa mengacu pada berbagai macam model peribadatan yang dianggap paling masuk akal dipraktikkan untuk memutus rantai penyebaran Covid-19 dan mewujudkan Daruratu Khams. ${ }^{17}$

\footnotetext{
${ }^{17}$ Muhamad Agus Mushodiq and Ali Imron, "Peran Majelis Ulama Indonesia Dalam Mitigasi Pandemi Covid-19 (Tinjauan Tindakan Sosial Dan Dominasi Kekuasaan Max Weber), ”Salam: Jurnal Sosial dan Budaya Syar-I 7, no. 5 (2020).
} 
TAHKIM, Jurnal Peradaban dan Hukum Islam. Vol.3 No.2 (0ktober, 2020) | ISSN : $2597-7962$

\section{SIMPULAN}

Secara faktual, upaya membangun kemaslahatan umat melalui fatwa oleh MUI merupakan suatu hal otentik yang tidak bisa dipungkiri. Peranan dan pengaruh fatwa MUI di masa pandemi sebagai wujud mitigasi covid-19 adalah langkah-langkah ideal dan strategis, sekalipun pada awalnya kemunculan fatwa tersebut sangatlah kontroversial penuh dinamika dan dilematika, bahkan lebih dari itu kehadiran fatwa tersebut banyak menuai berbagai macam kritikan dan respon negatif dari banyak kalangan masyarakat. Reaksi tersebut tidak lepas dari metode pembacaan fatwa yang menggunaan kacamata hitam putih, akhirnya secara normatif fatwa terlihat cenderung berisi laranagan-larangan yang irasional. Adapun indikator lain mengapa fatwa dimasa pandemi banyak menuai pertentangan adalah minimnya tingkat pengetahuan masyarakat terkait fatwa secara komprehensif. Namun belakangan ini eksistensi Fatwa MUI di masa pandemi dapat disikapi dengan positif dan diterima baik oleh seluruh kalangan masyarakat, bahkan pemerintah mengadopsi substansi dari fatwa-fatwa tersebut untuk dapat dijadikan landasan dasar dan rujukan dalam menciptakan semacam aturan atau kebijakan dalam bentuk regulasi yang berkekuatan hukum, berkaitan dengan gerakan preventif mencegah lajunya tingkat penyebaran virus corona di Indonesia. Lain dari itu, eksistensi fatwa MUI dimasa pandemi adalah wujud esensial dari alternatif dan solusi dalam menciptakan pola keberagamaan dan peribadatan yang lebih progresif, realistis, dinamis, dan kontekstualis, sekaligus menampilkan wajah Hukum Islam yang rahmatan lil alamin sholihul likulli zaman wal makan. 
TAHKIM, Jurnal Peradaban dan Hukum Islam. Vol.3 No.2 (0ktober, 2020) | ISSN : 2597-7962

\section{Buku :}

\section{DAFTAR PUSTAKA}

Amin, Makruf, (2000) Fatwa Dalam Kacamata Hukum Islam. Jakarta: Percetakan ElsaS.

Asrorun Ni'am Soleh, (2016), Metodologi Penetapan Fatwa Majelis Ulama Indonesia. Jakarta: Percetakan Emir.

Faried F. (2020) Saenong, Dkk. Fikih Pandemi Beribadah Di Masa Wabah. Nuo Publishing. Jakarta: Percetakan Gaya Media Pratama.

Idris, Abdul Fatah. (2007) Menggugat Istinbath Hukum Ibnu Qayyim Studi Kritik Terhadap Metode Penetapan Hukum Ibnu Qayyim Al-Jauziyah. Semarang: Percetakan Pustaka Zaman.

Muhajir, Noeng. (2016) Metodologi Penelitian Kuantitatif. Yogyakarta: Percetakan Raka Sarasin.

Penyusun, Tim. (2012) Fatwa Majelis Ulama Indonesia (MUI) Dalam Perspektif Hukum Dan Perundang-Undangan. Jakarta: Puslitbang Kehidupan Keagaamaan Badan Litbang dan Diklat Kementerian Agama RI.

Yeni, Barlinti Salma. (2010) Kedudukan Fatwa Dewan Syariah Naional Dalam Sistem Hukum Nasional Di Indonesia. Jakarta: Badan Litbang dan Diklat Kementerian Agama Republik Indonesia.

Muhajir, Noeng. (2016) Metodologi Penelitian Kuantitatif. Yogyakarta: Percetakan Raka Sarasin.

\section{Jurnal :}

Hendriyani, Hendriyani. (2017) “Analisis Isi: Sebuah Pengantar Metodologi yang Mendalam dan Kaya Dengan Contoh.” Jurnal Komunikasi Indonesia 2, no. 1.

Iswahyudi, (2017) “MUI Dan Nalar Fatwa-Fatwa Eksklusif.” Al-Ihkam: Jurnal Hukum \& Pranata Sosial 11, no. 2.

Mubarok, Jaih. (2013) “Dinamika Fatwa Produk Keuangan Syariah.” Ijtihad: Jurnal Wacana Hukum Islam dan Kemanusiaan 13, no. 1. 
TAHKIM, Jurnal Peradaban dan Hukum Islam. Vol.3 No.2 (0ktober, 2020) | ISSN : 2597-7962

Mudzhar, Mohamad Atho, and Khoirudin Nasution. (1994) "Hukum Keluarga Di Dunia Islam Modern.” Jurnal Mimbar Hukum 12.

Mushodiq, Muhamad Agus, and Ali Imron. (2020) “Peran Majelis Ulama Indonesia Dalam Mitigasi Pandemi Covid-19 (Tinjauan Tindakan Sosial Dan Dominasi Kekuasaan Max Weber)." Salam: Jurnal Sosial dan Budaya Syar-i 7, no. 5.

Wasik, Abdul, and Muhammad Muhammad. (2018) "Dasar Fatwa MUI Dalam Penerapan Hukum Islam (Telaah Atas Interaksi Sosial Dalam Perkembangan Hukum Islam Di Indonesia )" Jurnal Hukum dan Keislaman.

Yusuf, Muhammad. (2013) "Pendekatan Al-Mașlahah Al-Mursalah Dalam Fatwa MUI Tentang Pernikahan Beda Agama.” Ahkam : Jurnal Ilmu Syariah 13, no. 1. 
TAHKIM, Jurnal Peradaban dan Hukum Islam. Vol.3 No.2 (0ktober, 2020) | ISSN : 2597-7962 